\title{
Tissue Array Research Program
}

National Cancer Institute

\section{Source}

National Cancer Institute. Tissue Array Research Program. NCI Thesaurus. Code C16191.

The new T issue Array Research Program (TARP) is a collaborative effort between the National Human Genome Research Institute and NCI to continued advances in detection, diagnosis, and development of targeted cancer therapies. Among its aims are: 1) Advance tissue microarray technology research and development, 2) Produce tissue microarrays for use by the research community, 3) Serve as an arraying facility for groups with unique tissue materials, such as clinical trial groups or consortiums of rare diseases, 4) Disseminate tissue microarray technology by providing training, workshops, establishing protocols and standards. 